University of Nebraska - Lincoln

DigitalCommons@University of Nebraska - Lincoln

USDA National Wildlife Research Center - Staff Publications
U.S. Department of Agriculture: Animal and Plant Health Inspection Service

August 2004

\title{
Extensive contiguous north-south range expansion of the original population of an invasive lizard in Florida
}

\author{
Michaella M. Smith \\ Delray Beach, Florida \\ Henry T. Smith \\ Florida Department of Environmental Protection, Florida Park Service \\ Richard M. Engeman \\ USDA-APHIS-Wildlife Services, s_r100@yahoo.com
}

Follow this and additional works at: https://digitalcommons.unl.edu/icwdm_usdanwrc

Part of the Environmental Sciences Commons

Smith, Michaella M.; Smith, Henry T.; and Engeman, Richard M., "Extensive contiguous north-south range expansion of the original population of an invasive lizard in Florida" (2004). USDA National Wildlife Research Center - Staff Publications. 330.

https://digitalcommons.unl.edu/icwdm_usdanwrc/330

This Article is brought to you for free and open access by the U.S. Department of Agriculture: Animal and Plant Health Inspection Service at DigitalCommons@University of Nebraska - Lincoln. It has been accepted for inclusion in USDA National Wildlife Research Center - Staff Publications by an authorized administrator of DigitalCommons@University of Nebraska - Lincoln. 


\title{
Extensive contiguous north-south range expansion of the original population of an invasive lizard in Florida
}

\author{
Michaella M. Smith ${ }^{\mathrm{a}}$, Henry T. Smith ${ }^{\mathrm{b}}$, Richard M. Engeman ${ }^{\mathrm{c}, *}$ \\ a 11 Eastview Ave., Delray Beach, Florida 33483, USA \\ ${ }^{\mathrm{b}}$ Florida Department of Environmental Protection, Florida Park Service, 13798 S.E. Federal Highway, Hobe Sound, Florida 33455 , USA \\ ${ }^{\mathrm{c}}$ National Wildlife Research Center, USDA/Wildlife Services, 4101 LaPorte Ave., Fort Collins, Colorado 80521-2154, USA
}

\begin{abstract}
Florida has one of the two worst non-indigenous invasive species problems in the United States, and all such species are considered by statute to be a potential ecological problem. Unfortunately, little information is available about most of Florida's invasive species. Here, we provide information on range expansion of a population of one of the lesser-known species. The Palm Beach County, Florida, population of the northern curly-tailed lizard, Leiocephalus carinatus armouri, was examined for north-south expansion of its previously documented range. Observations were conducted as contiguous expansion outward from the previously known range. We found a substantial contiguous range expansion by a minimum of $46.3 \mathrm{~km}$ to the south and $34.1 \mathrm{~km}$ to the north. This species appears to be closely associated with coastal habitat degradation in the form of human infrastructure, especially ageing pavement, sea walls, buildings, and bridge bases.
\end{abstract}

(C) 2004 Elsevier Ltd. All rights reserved.

Keywords: Exotic species; Invasive species; Non-indigenous invasive species

\section{Introduction}

Non-indigenous invasive species are a major concern in Florida, the expectation that being that they will lead to "biotic impoverishment" while threatening the "natural functioning ability of Florida's ecosystems" (Schmitz and Brown, 1994). Florida and Hawaii are the states with the most severe problems of invasive species (US Congress, 1993). Recognition of the problems in Florida has led to implementation of strict laws against the introduction and transport of non-indigenous species within the state (Florida Statutes 372.265, Florida Administrative Code 39-4.005), and to Florida being one of the signatories of a letter to the Vice-President of US expressing concern over the problems wrought by non-indigenous invasive species (Schmitz and Brown, 1994, Appendix A). Unfortunately, little biological and ecological information is available for most of Florida's non-indigenous invasive species (US Congress, 1993). Here, we provide data on expansion from the original

\footnotetext{
* Corresponding author. Tel.: +1-970-266-6091; fax: +1-970-2666089.

E-mail address: richard.m.engeman@aphis.usda.gov (R.M. Engeman).
}

population of one such species for which little information exists, the northern curly-tailed lizard, Leiocephalus carinatus armouri.

This lizard is native to the islands of the Little Bahama Bank, with other subspecies in the Great Bahama Bank, Cayman Islands, and Cuba (Schwartz and Henderson, 1991). It was reported as an introduced species in Palm Beach County, Florida, by Duellman and Schwartz (1958). The introduction was reported to have been due to 20 pairs being released near Pendleton and Clarke Avenues, Palm Beach County, during the 1940s (Weigl et al., 1969). By 1959, its range had expanded to at least 20 city blocks (King, 1960; Weigl et al., 1969). The 1959 range boundaries were Royal Poinciana Way in the north, Clarke Avenue in the south, the Atlantic Ocean in the east, and the Intracoastal Waterway in the west (King, 1960). By 1968, the lizard was abundant as far as $3.21 \mathrm{~km}$ further north (Palm Beach Country Club) and $5.63 \mathrm{~km}$ further south (South Ocean and Segrape Circles), that is a range extension of ca. $4.02 \mathrm{~km}^{2}$ (Weigl et al., 1969). The total $8.8 \mathrm{~km}$ north-south expansion over 9 years represented an average annual range expansion of $0.9 \mathrm{~km}$ per annum. Weigl et al. (1969) believed that this species could further extend its range $2.85 \mathrm{~km}$ north to the Palm Beach Inlet, and south to 
the Boynton Beach Inlet at the southern end of Palm Beach Island, a distance of $12.2 \mathrm{~km}$. However, Smith and Engeman (2003) recently reported this species as abundant since 1986 at an apartment complex at Woolbright Road and the Intracoastal Waterway (ICW), an additional $3.4 \mathrm{~km}$ south of the southern limits suggested by Weigl et al. (1969). Furthermore, this species was recently reported to the north associated with human infrastructure in Martin County (Hauge and Butterfield, 2000; Smith and Engeman, 2002; Dean et al., 2004), which adjoins Palm Beach County in the north. Widely disjunct, allopatric populations have also been verified from the barrier island containing Cocoa Beach in Brevard County (Krysko and King, 2002), Chokoloskee Island, Collier County (McCoid, 2002) and Key Largo, Monroe County (J. Duquesnel, Florida Department of Environmental Protection, personal communication), with all observations associated with human infrastructure. Here, we report an investigation of the current northsouth range of the initial Palm Beach County population of the northern curly-tailed lizard.

\section{Methods}

Surveys in the Palm Beach County area were conducted to determine north-south range expansion: areas north and south of the 1968 range, following the Atlantic coastline, from 14 to 29 September, 2002, were surveyed. This survey strategy followed the urban/suburban development along the coast, which is often conducive to colonization by invasive species (US Congress, 1993). Surveys were conducted in a manner similar to those of Weigl et al. (1969) in the morning (08.00-10.00 $\mathrm{h}$ ) and afternoon (13.00-18.00), on sunny days when the lizards would be basking. A sports utility vehicle was used as a portable blind, although on some occasions the observers walked. Observations were made using $7 \times$ binoculars at major intersections with paved parking areas containing suitable habitat, such as sites with cracks or crevices and walls (Bartlett and Bartlett, 1999; Schwartz and Henderson, 1991). Latitude and longitude of each site and the numbers of adult and juvenile lizards observed were recorded. No attempt was made to estimate or index populations, nor to survey westward.

\section{Results}

Northern curly-tailed lizards were recorded at 45 locations (Table 1). No lizards were observed during replicate searches at the northernmost (Cove Road) and southernmost (NE 24th Street) sites, possibly defining the 2002 range boundaries of this population. The findings illustrate a contiguous range expansion of at least $46.3 \mathrm{~km}$ south, and $34.1 \mathrm{~km}$ north, beyond the 1968 range (Weigl et al., 1969). This represents a total north-south range expansion of $80 \mathrm{~km}$ in 34 years, or an average of about $2.4 \mathrm{~km}$ per annum. This rate of expansion is 2.7 times that for the nine years from 1959 to 1968 . Furthermore, the northernmost observation of this lizard is a Martin County range extension of $11.2 \mathrm{~km}$ beyond previous reports. Sightings typically were in association with walls, sea walls and other manmade habitat conversions containing structures with age-related gaps and recesses suitable for shelter, escape and concealment. Both adults and juveniles were observed at $60 \%$ of the sites where the lizard was observed. Juveniles were observed alone at $27 \%$ of sites and adults alone at $13 \%$. Thus, even a presenceabsence survey such as this indicated successful breeding at a minimum of $87 \%$ of the sites where this lizard was observed outwith the range described by Weigl et al. (1969).

\section{Discussion}

Problems caused by non-indigenous invasive species in Florida are among the most severe in the United States, with the state offering good conditions for expansion of the range of many species (US Congress, 1993). As with many other tropical herpetofauna introduced into South Florida, the Palm Beach County population of the northern curly-tailed lizard has expanded its range within the peninsula (Wilson and Porras, 1983; Butterfield et al., 1997; Bartlett and Bartlett, 1999). Wilson and Porras (1983) reported a strong correlation between population patchiness of non-indigenous amphibian and reptiles and habitat disturbance in Florida. Our survey findings also suggest a very strong preference of this lizard for disturbed habitats associated with anthropogenic structures, i.e. buildings, pavement, parking lots, etc., especially with age-related structural fractures or rubble cover). Likewise, other recent findings of this species also have been in and around habitats degraded by human infrastructure, e.g. buildings (Hauge and Butterfield, 2000), road intersections and parking lots (Krysko and King, 2002; Smith and Engeman, 2002; Dean et al., 2004), and recreational vehicle parks (McCoid, 2002). This is probably related to the type habitat occupied by the species in its native environments (Bartlett and Bartlett, 1999; Schwartz and Henderson, 1991). In other words, the northern curly-tailed lizard population expansion has followed the urban and suburban development along the southeastern coast of Florida, where disturbances caused by this development are prime locations for colonization by many non-indigenous invasive species (US Congress, 1993).

We have demonstrated a strong ability of this species to expand its range. Because little ecological information is available on the species, exact negative impacts by this animal on native species and ecosystems have not been defined. Wilson and Porras (1983) suggested that competition between introduced and indigenous herpetofauna probably was not a major conservation concern. In contrast, Butterfield et al. (1997) discuss "shift in habitat usage" by competing anole (Anolis) species in Florida and elsewhere. Bartlett and Bartlett (1999) summarize successional changes among 
Table 1

North to south range of observations of original northern curly-tailed lizard population in Florida

\begin{tabular}{|c|c|c|c|}
\hline Street location & County & Lat./long. coordinates & Specimens observed \\
\hline Cove Road at US Hwy. 1 & Martin & $\left(27^{\circ} 08^{\prime} \mathrm{N}, 80^{\circ} 12^{\prime} \mathrm{W}\right)$ & 0 adults $/ 0$ juveniles \\
\hline Bridge Road at US Hwy. 1 & Martin & $\left(27^{\circ} 03^{\prime} \mathrm{N}, 80^{\circ} 08^{\prime} \mathrm{W}\right)$ & 1 adult/0 juveniles \\
\hline (Sea Treasures) Gift Shop at US Hwy. 1 & Martin & $\left(26^{\circ} 58^{\prime} \mathrm{N}, 80^{\circ} 05^{\prime} \mathrm{W}\right)$ & 2 adults/ 1 juvenile \\
\hline County Line Road at US Hwy. 1 & Palm Beach & $\left(26^{\circ} 58^{\prime} \mathrm{N}, 80^{\circ} 05^{\prime} \mathrm{W}\right)$ & 1 adult/1 juvenile \\
\hline Beach Road at US Hwy. 1 & Palm Beach & $\left(26^{\circ} 57^{\prime} \mathrm{N}, 80^{\circ} 05^{\prime} \mathrm{W}\right)$ & 1 adult/1 juvenile \\
\hline Ocean Boulevard at US Hwy. 1 & Palm Beach & $\left(26^{\circ} 56^{\prime} \mathrm{N}, 80^{\circ} 05^{\prime} \mathrm{W}\right)$ & 1 adult/ 1 juvenile \\
\hline Indiantown Road at US Hwy. 1 & Palm Beach & $\left(26^{\circ} 56^{\prime} \mathrm{N}, 80^{\circ} 04^{\prime} \mathrm{W}\right)$ & 3 adults $/ 5$ juveniles \\
\hline Ocean Way at US Hwy. 1 & Palm Beach & $\left(26^{\circ} 55^{\prime} \mathrm{N}, 80^{\circ} 04^{\prime} \mathrm{W}\right)$ & 0 adults $/ 3$ juveniles \\
\hline Marcinski Road at US Hwy. 1 & Palm Beach & $\left(26^{\circ} 53^{\prime} \mathrm{N}, 80^{\circ} 03^{\prime} \mathrm{W}\right)$ & 1 adult/2 juveniles \\
\hline Donald Ross Road at US Hwy. 1 & Palm Beach & $\left(26^{\circ} 52^{\prime} \mathrm{N}, 80^{\circ} 03^{\prime} \mathrm{W}\right)$ & 2 adults $/ 2$ juveniles \\
\hline Juno Isles Blvd. at US Hwy. 1 & Palm Beach & $\left(26^{\circ} 51^{\prime} \mathrm{N}, 80^{\circ} 03^{\prime} \mathrm{W}\right)$ & 0 adults $/ 2$ juveniles \\
\hline PGA Boulevard at US Hwy. 1 & Palm Beach & $\left(26^{\circ} 50^{\prime} \mathrm{N}, 80^{\circ} 03 \mathrm{~W}\right)$ & 1 adult/ 1 juvenile \\
\hline Yacht Club Drive at US Hwy. 1 & Palm Beach & $\left(26^{\circ} 49^{\prime} \mathrm{N}, 80^{\circ} 03^{\prime} \mathrm{W}\right)$ & 0 adults $/ 6$ juveniles \\
\hline Lighthouse Drive at US Hwy. 1 & Palm Beach & $\left(26^{\circ} 49^{\prime} \mathrm{N}, 80^{\circ} 03^{\prime} \mathrm{W}\right)$ & 2 adults $/ 1$ juvenile \\
\hline Northlake Blvd. at US Hwy. 1 & Palm Beach & $\left(26^{\circ} 48^{\prime} \mathrm{N}, 80^{\circ} 03^{\prime} \mathrm{W}\right)$ & 0 adults $/ 2$ juveniles \\
\hline Silver Beach Road at US Hwy. 1 & Palm Beach & $\left(26^{\circ} 47^{\prime} \mathrm{N}, 80^{\circ} 03^{\prime} \mathrm{W}\right)$ & 0 adults $/ 1$ juvenile \\
\hline Blue Heron Blvd. at US Hwy. 1 & Palm Beach & $\left(26^{\circ} 46^{\prime} \mathrm{N}, 80^{\circ} 03^{\prime} \mathrm{W}\right)$ & 0 adults $/ 2$ juveniles \\
\hline Port Drive at US Hwy. 1 & Palm Beach & $\left(26^{\circ} 45^{\prime} \mathrm{N}, 80^{\circ} 03^{\prime} \mathrm{W}\right)$ & 1 adult $/ 0$ juveniles \\
\hline 45th Street at N Flagler Dr. & Palm Beach & $\left(26^{\circ} 45^{\prime} \mathrm{N}, 80^{\circ} 03^{\prime} \mathrm{W}\right)$ & 3 adults $/ 0$ juveniles \\
\hline 36th Street at N Flagler Dr. & Palm Beach & $\left(26^{\circ} 44^{\prime} \mathrm{N}, 80^{\circ} 03^{\prime} \mathrm{W}\right)$ & 1 adult/ 1 juvenile \\
\hline 23rd Street at N Flagler Dr. & Palm Beach & $\left(26^{\circ} 44^{\prime} \mathrm{N}, 80^{\circ} 02^{\prime} \mathrm{W}\right)$ & 2 adults $/ 0$ juveniles \\
\hline Fern Drive at S Flagler Dr. & Palm Beach & $\left(26^{\circ} 42^{\prime} \mathrm{N}, 80^{\circ} 03^{\prime} \mathrm{W}\right)$ & 0 adults $/ 1$ juvenile \\
\hline Belvedere Rd. at US Hwy. 1 & Palm Beach & $\left(26^{\circ} 41^{\prime} \mathrm{N}, 80^{\circ} 03^{\prime} \mathrm{W}\right)$ & 1 adult $/ 3$ juveniles \\
\hline Southern Blvd. at US Hwy. 1 & Palm Beach & $\left(26^{\circ} 40^{\prime} \mathrm{N}, 80^{\circ} 03^{\prime} \mathrm{W}\right)$ & 1 adult/ 0 juveniles \\
\hline Forest Hill Blvd. at US Hwy. 1 & Palm Beach & $\left(26^{\circ} 39^{\prime} \mathrm{N}, 80^{\circ} 03^{\prime} \mathrm{W}\right)$ & 2 adults $/ 0$ juveniles \\
\hline Yale Drive at US Hwy. 1 & Palm Beach & $\left(26^{\circ} 38^{\prime} \mathrm{N}, 80^{\circ} 03^{\prime} \mathrm{W}\right)$ & 0 adults $/ 2$ juveniles \\
\hline 10th Avenue $\mathrm{N}$ at US Hwy. 1 & Palm Beach & $\left(26^{\circ} 37^{\prime} \mathrm{N}, 80^{\circ} 03^{\prime} \mathrm{W}\right)$ & 1 adult/ 1 juvenile \\
\hline Lucerne Avenue at US Hwy. 1 & Palm Beach & $\left(26^{\circ} 37^{\prime} \mathrm{N}, 80^{\circ} 03^{\prime} \mathrm{W}\right)$ & 0 adults $/ 3$ juveniles \\
\hline 6th Avenue $\mathrm{S}$ at US Hwy. 1 & Palm Beach & $\left(26^{\circ} 36^{\prime} \mathrm{N}, 80^{\circ} 03^{\prime} \mathrm{W}\right)$ & 1 adult $/ 4$ juveniles \\
\hline 18th Avenue S at US Hwy. 1 & Palm Beach & $\left(26^{\circ} 35^{\prime} \mathrm{N}, 80^{\circ} 03^{\prime} \mathrm{W}\right)$ & 0 adults/ 1 juvenile \\
\hline Lantana Road at US Hwy. 1 & Palm Beach & $\left(26^{\circ} 35^{\prime} \mathrm{N}, 80^{\circ} 03^{\prime} \mathrm{W}\right)$ & 1 adult/1 juvenile \\
\hline Hypoluxo Road at US Hwy. 1 & Palm Beach & $\left(26^{\circ} 34^{\prime} \mathrm{N}, 80^{\circ} 03^{\prime} \mathrm{W}\right)$ & 3 adults $/ 3$ juveniles \\
\hline Gateway Blvd. at US Hwy. 1 & Palm Beach & $\left(26^{\circ} 32^{\prime} \mathrm{N}, 80^{\circ} 03^{\prime} \mathrm{W}\right)$ & 2 adults $/ 1$ juvenile \\
\hline Boynton Beach Blvd. at US Hwy. 1 & Palm Beach & $\left(26^{\circ} 31^{\prime} \mathrm{N}, 80^{\circ} 03^{\prime} \mathrm{W}\right)$ & 1 adult/2 juveniles \\
\hline Woolbright Rd. at ICW & Palm Beach & $\left(26^{\circ} 30^{\prime} \mathrm{N}, 80^{\circ} 03^{\prime} \mathrm{W}\right)$ & 1 adult/2 juveniles \\
\hline George Bush Blvd. at ICW & Palm Beach & $\left(26^{\circ} 28^{\prime} \mathrm{N}, 80^{\circ} 03^{\prime} \mathrm{W}\right)$ & 2 adults $/ 3$ juveniles \\
\hline Atlantic Avenue at ICW & Palm Beach & $\left(26^{\circ} 27^{\prime} \mathrm{N}, 80^{\circ} 04^{\prime} \mathrm{W}\right)$ & 1 adult/3 juveniles \\
\hline Linton Blvd. at ICW & Palm Beach & $\left(26^{\circ} 26^{\prime} \mathrm{N}, 80^{\circ} 04^{\prime} \mathrm{W}\right)$ & 4 adults $/ 5$ juveniles \\
\hline C-15 Canal at US Hwy. 1 & Palm Beach & $\left(26^{\circ} 25^{\prime} \mathrm{N}, 80^{\circ} 04^{\prime} \mathrm{W}\right)$ & 1adult/3 juveniles \\
\hline Spanish River Blvd. at ICW & Palm Beach & $\left(26^{\circ} 23^{\prime} \mathrm{N}, 80^{\circ} 04^{\prime} \mathrm{W}\right)$ & 0 adults/ 1 juvenile \\
\hline Palmetto Park Road at ICW & Palm Beach & $\left(26^{\circ} 21^{\prime} \mathrm{N}, 80^{\circ} 04^{\prime} \mathrm{W}\right)$ & 1 adult $/ 4$ juveniles \\
\hline Boca Beach Club at SR A-1-A & Palm Beach & $\left(26^{\circ} 20^{\prime} \mathrm{N}, 80^{\circ} 04^{\prime} \mathrm{W}\right)$ & 0 adults $/ 3$ juveniles \\
\hline South Inlet Park at SR A-1-A & Palm Beach & $\left(26^{\circ} 20^{\prime} \mathrm{N}, 80^{\circ} 04^{\prime} \mathrm{W}\right)$ & 1 adult/2 juveniles \\
\hline Hillsboro Blvd. at ICW & Broward & $\left(26^{\circ} 18^{\prime} \mathrm{N}, 80^{\circ} 04^{\prime} \mathrm{W}\right)$ & 4 adults $/ 7$ juveniles \\
\hline SE 10th Street at US Hwy. 1 & Broward & $\left(26^{\circ} 18^{\prime} \mathrm{N}, 80^{\circ} 05^{\prime} \mathrm{W}\right)$ & 1 adult/ 1 juvenile \\
\hline NE 29th Street at US Hwy. 1 & Broward & $\left(26^{\circ} 16^{\prime} \mathrm{N}, 80^{\circ} 05^{\prime} \mathrm{W}\right)$ & 2 adults/1 juvenile \\
\hline NE 24th Street at US Hwy. 1 & Broward & $\left(26^{\circ} 15^{\prime} \mathrm{N}, 80^{\circ} 05^{\prime} \mathrm{W}\right)$ & 0 adults $/ 0$ juvenile \\
\hline
\end{tabular}

gecko populations in south Florida as new species have been introduced. Most compelling evidence has been provided by Schoener et al. (2002), who reported that experimental introduction of the northern curly-tailed lizard had an immediate and major effect on the population density of the brown anole, A. sagrei, its height of perch and other characteristics. Even although the brown anole is another invasive species in Florida (Bartlett and Bartlett, 1999; Schmitz and Brown, 1994), the fact that the northern curly-tailed lizard could adversely affect them so rapidly leads to the logical assumption that native fauna have been, or will be, affected by this species. A variety of native lizards overlap its range and habitat (Bartlett and Bartlett, 1999), possibly putting them at risk of predation, competition and disease transmission. Recent studies have demonstrated the negative impacts from invasive species to rare and endangered native species on an economic basis (Engeman et al., 2002, 2003). Sufficient data for the impacts of northern curly-tailed lizards have not yet been generated to carry out such an analysis. More to the point, all non-indigenous 
invasive species in Florida are considered undesirable and potentially harmful, even if specific negative impacts have not yet been identified (US Congress, 1993; Schmitz and Brown, 1994).

Our findings suggest that within the range of survey along the Atlantic coastline of Florida, amidst a patchy mosaic of urban, suburban and wildlands, most of the habitat that is suitable for it is now occupied by this lizard. Considerable additional surveying will be required to document the inland (westward) range of this population. The precise effects of this species on the native lizards and other fauna of Florida remain largely unexplored and should therefore also be examined. The negative effects of invasive reptiles may not be readily or immediately apparent. As a prime case in point, the devastating effects of the invasive brown tree snake on Guam was not recognized for decades, and effective remedies to the problem have required further decades of research (Engeman and Vice, 2002).

\section{References}

Bartlett, R.D., Bartlett, P.P., 1999. A field guide to Florida reptiles and amphibians. Gulf Publishing, Houston, Texas.

Butterfield, B.P., Meshaka, W.E., Guyer, C., 1997. Non-indigenous amphibians and reptiles. In: Simberloff, D., Schmitz, D.C., Brown, T.C. (Eds.), Strangers in Paradise. Island Press, Washington, DC, pp. 123-138.

Dean, C.L., Smith, H.T., Engeman, R.M., 2004. Leiocephalus carinatus armouri (little bahama curly-tailed lizard), USA: Florida: St. Lucie Co. Herpetological Review 35, 82.

Duellman, W.E., Schwartz, A., 1958. Amphibians and reptiles of southern Florida. Bulletin Florida State Museum 3, 181-342.

Engeman, R.M., Vice, D.S., 2002. Objectives and integrated approaches for the control of brown tree snakes. Integrated Pest Management Reviews 6, 59-76.

Engeman, R.M., Shwiff, S.A., Constantin, B., Stahl, M., Smith, H.T., 2002. An economic analysis of predator removal approaches for protecting marine turtle nests at Hobe Sound National Wildlife Refuge. Ecological Economics 42, 469-478.

Engeman, R.M., Shwiff, S.A., Cano, F., Constantin, B., 2003. An economic assessment of the potential for predator management to benefit Puerto rican parrots. Ecological Economics 46, 283-292.

Hauge, J.B., Butterfield, B.P., 2000. Leiocephalus carinatus armouri (northern curlytail lizard), USA: Florida: Martin Co. Herpetological Review 31, 53.

King, W., 1960. New populations of West Indian reptiles and amphibians in southeastern Florida. Quarterly Journal of the Florida Academy of Sciences 23, 71-73.

Krysko, K.L., King, F.W., 2002. Leiocephalus carinatus armouri (little bahama curly-tailed lizard), USA: Florida: Brevard Co. Herpetological Review 33, 148.

McCoid, M.J., 2002. Leiocephalus carinatus (curly-tailed lizard), USA: Florida: Collier Co. Herpetological Review 33, 322.

Schmitz, D.C., Brown, T.C., 1994. An assessment of invasive non-indigenous species in Florida's public lands. Technical Report TSS-94-100. Florida Department of Environmental Protection, Tallahassee, FA.

Schoener, T.W., Spiller, D.A., Losos, J.B., 2002. Predation of a common Anolis lizard: can the food-web effects of a devastating predator be reversed? Ecological Monographs 72, 383-407.

Schwartz, A., Henderson, R.W., 1991. Amphibians and Reptiles of the West Indies: Descriptions, Distributions and Natural History. University of Florida Press, Gainesville, FA.

Smith, H.T., Engeman, R.M., 2002. An earlier report of the exotic northern curly-tailed lizard in Martin County, Florida. Florida Field Naturalist 30, 132-133.

Smith, H.T., Engeman, R.M., 2003. Leiocephalus carinatus armouri (Northern curly-tailed lizard) opportunistic predation. Herpetological Review 34, 245-246.

US Congress, 1993. Harmful Non-indigenous Species in the United States. Office of Technology Assessment, OTA-F-565, Government Printing Office, Washington, DC.

Weigl, G.L., Domey, R.G., Courtenay, W.R., 1969. Survival and range expansion of the curly-tailed lizard, Leiocephalus carinatus armouri, in Florida. Copeia 1969, 841-842.

Wilson, L.D., Porras, L., 1983. The ecological impact of man on the South Florida herptofauna. University of Kansas Museum of Natural History, Special Publication, Vol. 9, pp. 1-89. 